\title{
FOI AND THE FREedom OF POLITICAL COMMUNICATION
}

\author{
ANTHONY GRAY*
}

[There are very few freedom of information cases that have been heard by the High Court of Australia and this article discusses freedom of information rights in the context of the Court's recent important decision in McKinnon. After reviewing the judgments in the case, the author advocates that freedom of information rights must not be seen in isolation, but in the context of broader constitutional rights, including the implied right to political freedom of communication, as well as the doctrine of representative government. It is suggested that the effect of the decision is to unduly narrow the rights citizens would otherwise have under freedom of information laws, and is contrary to the spirit of such laws. It compromises the ability of the sovereign people to exercise that sovereignty over their elected representatives. Placing freedom of information rights into this broader constitutional perspective, the decision can be seen as out of step with the Constitution and its prescribed system of government. More broadly, it is considered that freedom of information principles must be interpreted within the existing constitutional rights framework.]

\section{INTRODUCTION}

It will first be necessary to explain the context in which the decision made, and go into some detail on the various judgments. The decision in McKinnon $v$ Secretary, Department of Treasury ${ }^{I}$ considered the scope of the Commonwealth freedom of information laws, in the particular context where a Minister had issued a certificate to the effect that disclosure of the requested information would be contrary to the public interest. A newspaper had

\footnotetext{
${ }^{*}$ Senior Lecturer, School of Law, University of Southern Queensland.

${ }^{1}$ [2006] 80 ALJR 1549
} 
requested information regarding tax bracket creep and the Government's first home owners' scheme. Of course, the object of freedom of information legislation is to provide greater openness and accountability in government decision making. Section 3(1) of the Freedom of Information Act 1982 (Cth)(FOI Act) states the Act seeks to extend as far as possible the right of the Australian community to information in the possession of the Commonwealth government, limited only by exceptions and exemptions necessary for the protection of essential public interests and the private and business affairs of those in respect of whom information is collected. Applying general principles of statutory interpretation, the Act specifically states that the Act should be interpreted to further the object of the Act $(\mathrm{s} 3(2))$.

The relevant exemption in this case is contained in s36 of the FOI Act, providing for the non-disclosure of a document that satisfied two conditions:

(a) it contained matter in the nature of, or relating to, opinion, advice or recommendation obtained, prepared or recorded or deliberation that has taken place, in the course of deliberative process involving an agency or Minister; and

(b) disclosure would be contrary to the public interest.

(Similar provisions appear in freedom of information laws at the State level). ${ }^{2}$

Section 36(3) of the Act allowed a Minister to sign a certificate which, while current, would establish conclusively that the second condition for exemption was fulfilled. Such an action was amenable to review, but of a more limited nature than that provided for elsewhere in the Administrative Appeals Tribunal Act 1975 (Cth)(AAT Act). The function of the review tribunal in such a case was not to consider the merits of the decision that disclosure was not in the public interest; it was confined to the more limited consideration of whether there existed reasonable grounds for the claim that disclosure would be contrary to the public interest (s58(5) of the FOI Act). The Act required the Minister in such a case to specify the ground of public interest upon which he or she relied.

\section{A Request in this Case}

In this case, an employee of The Australian sought access to two kinds of document - those relating to tax 'bracket creep', and those relating to the first

\footnotetext{
${ }^{2}$ Eg s59 Freedom of Information Act 1989 (NSW), s28 Freedom of Information Act 1982 (Vic), s36,s37 and s42 of the Freedom of Information Act 1992 (Qld)
} 
home owners' scheme. The Commonwealth Treasury identified almost one hundred documents relevant to the request, but claimed that most of the documents were exempt. After the applicant commenced legal proceedings to challenge this decision, the Treasurer signed two certificates under s36(3) of the Act to the effect that disclosure of most of the documents identified by the Department in its search would be contrary to the public interest. Specifically, it was claimed that:

(a) government officers should be able to communicate directly, freely and confidentially with the Minister on sensitive matters;

(b) officers should be able to freely reduce to writing what they would otherwise do orally; if they were to be released for public scrutiny, officers may in future be reluctant to make a written record, to the detriment of the process and the public record;

(c) release of a document discussing options that were not settled at the time of drafting and outlining options not ultimately taken could be likely to mislead and confuse the public and undermine the government's public integrity

(d) release may be confusing or misleading given its provisional nature

(e) release of documents with different versions of estimates, projections, costings and other numerical analysis may confuse the public and would not make a valuable contribution to public debate and could again undermine the government's public integrity

(f) the preparation of possible responses to questions in Parliament was a very sensitive aspect of the department's work and should remain confidential;

(g) the release of documents intended for a specific audience familiar with technical terms and jargon used could lead to public misunderstanding; they do not contain sufficient information for an uninformed audience to interpret them correctly or reasonably.

Broadly, these concerns revolved around confidentiality and the misleading nature of the disclosed information.

The applicant appealed to the Tribunal for a review of the decision that release of the documents would be contrary to the public interest. Due to the precise wording of s58(5) of the Act, this could only be on the basis that there were no reasonable grounds for the making of the Minister's decision in this regard. To re-iterate, this was not a typical merits review typically undertaken by the Administrative Appeals Tribunal. It was not to re-open the question whether in fact disclosure would be contrary to the public interest. The 
Tribunal determined there were reasonable grounds for the claim that disclosure would be contrary to the public interest.

This was affirmed by the Full Federal Court by $2-1 .^{3}$ The main point of contention here was the nature of the review process undertaken by the Tribunal in the case of a Ministerial conclusiveness certificate. Tamberlin and Jacobson JJ had a narrow view of such a process. According to the majority, the Tribunal should not undergo a weighing or balancing exercise in order to exercise its power of review under s58(5). It was enough to confirm the Minister's certificate that grounds existed that were not irrational, absurd or ridiculous. ${ }^{4}$ This was important because here the Tribunal had not considered in any detail evidence from experts retained by the applicant in this case who believed that disclosure of these documents was in the public interest. The Tribunal did not think that the exercise of its power in s58(5) required them to consider such evidence. In dissent, Conti $\mathrm{J}$ thought that a balancing exercise was required. Referring to a High Court decision involving the requirement for reasonable evidence to support an application for a search warrant, he concluded

Rationality, or the quality of being rational, the possession of reason, or the reaching of a rational or reasonable view, in accordance with the George $v$ Rockett thesis, is not to be objectively attained or achieved, according to the submissions of the appellant which I would favour, by a decision maker exercising a statutory function of review in the absence of his or her balancing (or weighing) objectively differing and competing views not unreasonably open to be adopted ${ }^{5}$

\footnotetext{
${ }^{3}$ Per Tamberlin and Jacobson JJ, Conti J dissenting

${ }^{4}$ McKinnon v Secretary, Department of Treasury (2005) 145 FCR 70,76,140, citing cases such as Department of Industrial Relations v Burchill (1991) 33 FCR 122; Australian Doctors' Fund Ltd v Commonwealth (1994) 49 FCR 478; Re Porter and Department of Community Services and Health (1988) 14 ALD 403; Re Waterford and Treasurer (No 2)(1985) 8 ALN N37, Re Peters and Prime Minister and Cabinet (No 2)(1983) 5 ALN N306; Re MacPhee and Department of Treasury (1989) 11 AAR 166

${ }^{5}$ 88. The so-called George v Rockett thesis, George v Rockett (1990) 170 CLR 104, involved the High Court unanimously adopting an old statement from Bowden $v$ Box [1916] GLR 443, 444 in respect of a similarly worded provision, that 'it is impossible to construe this enactment as an authority to a justice to issue a search warrant upon the oath alone of a constable or of any other person that 'there is reasonable ground to believe that liquor is sold' etc. So to hold would be to hold that the justice may discharge the judicial duty cast upon him by acting, parrot-like, upon the bald assertion of the informant'.
} 
Given his view that the Tribunal had not weighed and balanced the evidence of the appellant's witnesses, he would have remitted the matter back to the Tribunal on the basis of an error of law.

The applicant then appealed to the High Court. ${ }^{6}$

\section{B High Court Majority View}

By majority, the High Court dismissed the appeal from the decision of the Full Federal Court, upholding the original Tribunal decision that reasonable grounds existed for the belief, so in effect the material did not need to be disclosed. Callinan and Heydon JJ accepted most of the reasoning from the Department of Treasury as to why disclosure should not be allowed. Specifically, these judges accepted the argument by Treasury that the documents were interim in nature, involving some recommendations that were not adopted. They concluded that it would be difficult to see how it would not be reasonable for a Minister to take the view that the release of material of that kind would not make a valuable contribution to public debate. ${ }^{7}$ They upheld the reasonableness of Treasury's view that disclosure might jeopardize candour and discourage written communication within government, on the basis that the 'Minister's opinion and experience are likely to be as well informed and valuable as those of anyone else' ${ }^{8}$ Callinan and Heydon JJ accepted the reasonableness of the argument that documents prepared for possible responses to questions in Parliament should remain confidential 'because their exposure would threaten the Westminster system of government, that is to say responsible government ... that cannot be said to be an unreasonable view'. ${ }^{9}$ The joint judgment did not accept the argument from Treasury that disclosure should be prohibited because members of the public may not understand the technicalities or jargon used in the documents, ${ }^{10}$ on the basis that experts could assist in interpreting the information.

The joint judgment agreed with the majority of the Full Federal Court that the process under s36(3) did not involve balancing a number of considerations. It

\footnotetext{
${ }^{6}$ The applicant could have, but did not, apply to the Federal Court for judicial review under the Administrative Decisions (Judicial Review) Act 1977 (Cth).

${ }^{7} 1575$; Hayne J agreed

${ }^{8} 1575$

${ }^{9} 1575$

${ }^{10} 1576$
} 
agreed with the view of the Full Federal Court that in effect if one reasonable ground for the claim of contrariety to the public interest exists then, although there may be reasonable grounds the other way, the conclusiveness would be beyond review. ${ }^{11}$ Curiously, the joint judges reached this conclusion, although acknowledging that the approach they applied may lead to the 'practical consequence ... that one or more of the stated objects of the Act are thereby defeated'. ${ }^{12}$ They concluded that the test mentioned in s36(3) should not be para-phrased into another test. ${ }^{13}$ Callinan and Heydon JJ left open the question then whether 'the only practical and real means of attacking a conclusive certificate will be by demonstrating that there are no reasonable grounds in fact, or that the grounds relied on are so unreasonable that no reasonable person could hold the opinions upon which they are based'. ${ }^{14}$ They denied that the test of public interest was 'multi-faceted'. ${ }^{15}$ As indicated, although agreeing with the majority view, Hayne $J$ differed in some respects, including a rejection of the argument that the existence of at least one non-absurd ground justifying non-disclosure was sufficient to dispose of the case. ${ }^{16}$ Hayne $\mathrm{J}$ concluded that the Tribunal had exercised the review power responsibly, and had not fallen into the error of treating the 'class' of documents to which those in question belonged as conclusive as to the question of their eligibility for release. ${ }^{17}$

\section{High Court Minority View}

Gleeson CJ and Kirby $\mathrm{J}$ quoted a passage from Tamberlin $\mathrm{J}$ of the Full Federal Court indicating that provided there was a ground that was not irrational, absurd or ridiculous for a claim that the public interest required non-disclosure, s58(5) of the Act would be satisfied. One example given by

${ }^{11} 1576$. This is in contrast with the position of Hayne $J$, that the mere fact that one reason was non-absurd was sufficient to find the existence of reasonable grounds (1563).

121576 ; they justified their conclusion on the basis it was required by the clear words of the relevant sections of the Act.

${ }^{13}$ Hayne J agreed (1562). An alternative test that had been considered in lower courts was that the decision was reasonable provided it was not irrational, absurd or ridiculous.

141576

${ }^{15}$ Callinan and Heydon JJ claimed that the fact that different people would see public interest through different prisms and that it was a difficult thing to define did not mean it was multi-faceted.

${ }^{16} 1563$

${ }^{17} 1564-1565$ 
that Court was that it was desirable that inter-governmental communications by kept confidential. The minority judges did not accept this approach. If it were accepted, they claimed, then every decision by the Minister to issue the non-disclosure certificate could be justified on the basis of confidentiality of government communication. The applicant would never be able to succeed with their application, because every non-disclosure of a government document could be justified on this basis. ${ }^{18}$ In stark contrast to the majority, the minority stated that the public interest was a multi-faceted concept. ${ }^{19}$ As a result, the circumstance that there is something relevant to be put against disclosure was not the end of the matter; it was the beginning. The Tribunal was required to take into account all relevant considerations.

In contrast to the dissenting judge Conti $\mathrm{J}$ in the Full Federal Court, however, the minority in the High Court denied it was a balancing exercise, stating that the FOI Act was instead premised on disclosure of information as the general principle, subject to exceptions and exemptions in some cases. ${ }^{20}$ The minority would have set aside the decision of the Full Federal Court and Tribunal, and ask that the Tribunal again consider the matter.

It is submitted there are two main bases on which to critique the judgment of the majority in this case. It is said that the decision is inconsistent with the Constitution in that:

(a) it did not take into account the constitutionally implied freedom of communication about political matters and the requirements of representative government in interpreting the Act; and

(b) the techniques used to assess the reasons for non-disclosure, as well as the reasons themselves accepted by the Court, are open to question, given their consequences for a strong separation of powers, which is mandated by the Constitution.

These broad principles will now be further explored in the context of FOI rights.

${ }^{18}$ Cf Minister for Immigration and Multicultural Affairs v Yusuf (2001) 206 CLR 323; Minister for Immigration and Multicultural Affairs v Rajamanikkam [2002]

HCA 32 where a similar argument that all relevant factors should be taken into account was rejected by the majority. There is a contrary line of reasoning that, to the extent that the minority view can be assimilated with an argument as to Wednesbury reasonableness, it is not appropriate to this case, involving as it does a duty rather than exercise of discretion.

${ }^{19} 1554$

${ }^{20} 1554-1555$ 


\section{Freedom of COMMUNICATION ABOUt Political MATTERS AND REPRESENTATIVE GOVERNMENT}

One of the grounds on which the decision can be questioned is that it did not consider the applicability to the case of some implied freedoms that the High Court has previously found to exist in the Constitution. It is submitted that these freedoms are directly relevant to a consideration of the meaning of FOI law. There are clear links between freedom of communication about political affairs, and the objects of FOI law. ${ }^{21}$

In a series of cases, the High Court has confirmed that Australians enjoy an implied constitutional right to freedom of communication in political matters. ${ }^{22}$ The basis of the implied right is the idea that the Australian Constitution contemplates a system of representative government, which can only work effectively if citizens have a right to communicate about political issues. Mason CJ in the Australian Capital Television case made the connection between freedom of information and the constitutional right in these terms:

Communication in the exercise of the freedom is by no means a one-way traffic, for the elected representatives have a responsibility not only to ascertain the views of the electorate but also to explain and account for their

${ }^{21}$ See for example Bill Lane and Chris Gilbert Administrative Law in Queensland (2001) $2^{\text {nd }}$ ed p163: 'More recently, the foundation objectives of FOI have found support in developments in Australian constitutional law concerning implied rights under the Australian Constitution'.

${ }^{22}$ For example Australian Capital Television Pty Ltd v Commonwealth (1992) 177 CLR 106; Nationwide News Pty Ltd v Wills (1992) 177 CLR 1; and Lange v Australian Broadcasting Corporation (1997) 189 CLR 520. These cases are the subject of an extensive literature - refer for example to Glenn Patmore 'Making Sense of Representative Democracy and the Implied Freedom of Political Communication in the High Court of Australia' (1998) 7 Griffith Law Review 97; Michael Coper 'The High Court and Free Speech: Visions of Democracy or Delusions of Grandeur?' (1994) 16 Sydney Law Review 185; Nicholas Aroney 'A Seductive Plausibility: Freedom of Speech in the Constitution' (1995) 18(2) University of Queensland Law Journal 249; Jeffrey Goldsworthy 'Constitutional Implications and Freedom of Political Speech: A Reply to Stephen Donaghue' (1997) 23 Monash University Law Review 362; P Creighton 'The Implied Guarantee of Free Political Communication' (1993) 23 University of Western Australia Law Review 163; H P Lee 'The Australian High Court and Implied Fundamental Guarantees' (1993) Public L 606; and Adrienne Stone 'Rights, Personal Rights and Freedoms: the Nature of the Freedom of Political Communication under the Australian Constitution' (1998) 21 University of New South Wales Law Journal 117 
decisions and actions in government and to inform the people so that they may make informed judgments on relevant matters. Absent such a freedom of communication, representative government would fail to achieve its purpose, namely government by the people through their elected representatives; government would cease to be responsive to the needs and wishes of the people and, in that sense, would cease to be truly representative ... individual judgment ... on so many issues turns upon free public discussion in the media of the views of all interested persons, groups and bodies and on public participation in, and access to, that discussion. ${ }^{23}$

Mason CJ concluded that the court should be astute not to accept at face value claims by the legislature and executive that freedom of communication will, unless curtailed, bring about corruption and distortion of the political process. ${ }^{24}$ McHugh $\mathrm{J}$ in the same case agreed that voters had a constitutional right to convey and receive opinions, arguments and information concerning matter likely or intended to affect voting in an election. ${ }^{25}$ This was said to be because in order that representative and responsible government could operate effectively and as the Constitution intended. Brennan $\mathrm{J}$ in the same case agreed that freedom of political discussion was essential to the democratic process. ${ }^{26}$

\section{As Mason CJ said in $A C T v C t h$ :}

Members of Parliament and Ministers are accountable to the people for what they do and have a responsibility to take into account of the views of the people on whose behalf they act ... Indispensable to that accountability and that responsibility is freedom of communication,

${ }^{23}$ (1992) 177 CLR 106,139

${ }^{24} \mathrm{P} 139$

${ }^{25} \mathrm{P} 232$; 'if the institutions of representative and responsible government are to operate effectively and as the Constitution intended, the business of government must be examinable and the subject of scrutiny, debate and ultimate accountability at the ballot box. The electors must be able to ascertain and examine the performances of their elected representatives and the capabilities and policies of all candidates for election. Before they can cast an effective vote at election time, they must have access to the information, ideas and arguments which are necessary to make an informed judgment as to how they have been governed and as to what policies are in the interests of themselves, their communities and the nation ... the ability of the people to make informed choices among candidates for political office is fundamental because the identity of those who are elected will shape the nation's destiny (231)

${ }^{26} \mathrm{P} 159$ 
at least in relation to public affairs and political discussion ... In a free democratic society, it is almost too obvious to need stating that those who hold office in government and who are responsible for public administration must always be open to criticism. Any attempt to stifle or fetter such criticism amounts to political censorship of the most insidious and objectionable kind. ${ }^{27}$

In Theophanous $v$ Herald and Weekly Times Ltd, Deane J agreed that:

The freedom of the citizen to examine, discuss and criticise the suitability for office of the elected members of the Parliament and the manner in which they discharge their functions and duties as such lies at the very heart of the freedom which the implication of freedom of communication protects. ${ }^{28}$

The High Court unanimously accepted in Lange that the:

Common convenience and welfare of Australian society are advanced by discussion - the giving and receiving of information about government and political matters (emphasis added) ${ }^{29}$

In Egan $v$ Willis, a case involving ministerial obligations to answer questions in, and to table documents to, the New South Wales Legislative Council, Gaudron, Gummow and Hayne JJ noted:

It has been said of the contemporary position in Australia that, whilst the primary role of Parliament is to pass laws, it also has important functions to question and criticise government on behalf of the people and that 'to secure accountability of governmental activity is the very essence of responsible government ... In Australia s75(v) of the Constitution and judicial review of administrative action under federal and State law, together with freedom of information legislation, supplement the operation of responsible government in this respect. $^{30}$

27 (1992) 177 CLR 106, 138 (partly quoting Derbyshire County Council v Times Newspapers Ltd [1993] AC 534, 548 per Lord Keith)

${ }^{28}$ (1994) 124 ALR 1, 58; refer also to ACT v Cth (1992) 177 CLR 106, per Mason CJ (140) and McHugh J (231)

${ }^{29}$ Lange v Australian Broadcasting Corporation (1997) 189 CLR 520, 571

${ }^{30}$ (1998) 195 CLR 424, 451 
Importantly, these rights have been found to limit both legislative and executive power. $^{31}$

Certainly, the High Court of Australia has been at pains to make clear that the right to political free speech is not a positive, personal right, but rather a 'freedom from governmental action'. ${ }^{32}$ The court was clear in Lange $v$ Australian Broadcasting Corporation that the sections from which the implied right to political free speech were implied:

Do not confer personal rights on individuals. Rather they preclude the curtailment of the protected freedom by the exercise of legislative or executive power ... they are a limitation or confinement of laws and powers which give rise to a pro tanto immunity on the part of the citizen from being adversely affected by those laws or by the exercise of those powers ${ }^{33}$

In the McKinnon litigation, the appellant led arguments based on the implied freedom of political communication. Conti $\mathrm{J}$ in the Full Federal Court specifically acknowledged them, citing ACT $v$ Commonwealth and other cases, and concluded they were relevant to this case. ${ }^{34}$

The argument then is that the Minister's apparently unbridled power to issue a certificate that disclosure of information would be contrary to the public interest is limited by the right of individuals to political communication, which as the High Court has itself recognised, requires access to government-

\footnotetext{
${ }^{31}$ Theophanous $v$ Herald and Weekly Times Ltd (1994) 182 CLR 104, 149; Lange v Australian Broadcasting Corporation (1997) 189 CLR 520, 560 (Brennan CJ, Dawson Toohey Gaudron McHugh Gummow and Kirby JJ), Mulholland v Australian Electoral Commission (2004) 220 CLR 181, 245 (Gummow and Hayne $\mathrm{JJ})$. The case of Bennett $v$ President, Human Rights and Equal Opportunity Commission (2003) 134 FCR 334 is one example where a regulation prohibiting a member of the Australian Public Service from giving or disclosing any information about public business or anything of which the employee has official knowledge was invalidated as being an unreasonable burden upon the constitutional freedom. Refer also to the right discussed in the context of a member of the police service, a member of the Executive, in Coleman v Power (2004) 209 ALR 182

${ }^{32}$ Hayne J in McClure v Australian Electoral Commission (1999) 163 ALR 734, $740-741$

33 (1997) 189 CLR 520, 560 (Brennan CJ, Dawson Toohey Gaudron McHugh Gummow and Kirby JJ)

${ }^{34} 110$; 'it can scarcely be said that those observations have no bearing at all upon the issues arising at the Tribunal hearing'.
} 
held information. ${ }^{35}$ Just as the High Court said in Lange that statutory defamation law are construed, if possible, conformably with the Constitution, but that if they conflict with the constitutional right, must yield to it, ${ }^{36}$ so here we accept the Minister's right to issue a certificate, but require it must be exercised in conformity with the constitutional freedom. It means that the Minister's certificate issuing power cannot be exercised in relation to matters falling within the definition of 'political issue' unless it meets the second of the Lange conditions, to which we will shortly turn. Of course, to the extent that the minister's power to issue certificates relates to an issue that is not considered to be 'political', it is a power unaffected by the freedom of political communication.

The author submits that in most federal election campaigns, the taxation policy of each of the political parties is a key issue likely to affect voting in an election. The release of information about bracket creep regarding taxation, or the impact of a key government policy to assist first home buyers, would assist voters in their decision on the effectiveness of the government of the day, or the relative merits of the policies of other political parties. These are clearly political matters. If further evidence be needed, Conti $\mathrm{J}$ in the Full Federal Court noted that income tax bracket creep and the first home owner's scheme had 'apparently occupied at least the financial and political segments of the media for some time' ${ }^{37}$ Consistently with the right to freedom of communication, it is submitted that citizens should be able to read government documents in relation to these important political issues.

The High Court in Lange reinterpreted the political right to freedom of speech in terms of two tests:

(a) whether the law effectively burdens freedom of communication about government or political matters in its terms, operation or effect; and

(b) if so, is it reasonably appropriate and adapted to serve a legitimate end the fulfilment of which is compatible with the maintenance of the constitutionally prescribed system of representative and responsible government $^{38}$

\footnotetext{
${ }^{35}$ Or, somewhat pedantically, that legislation or executive action not inhibit this right.

${ }^{36} 566$

${ }^{37} 80$

${ }^{38} 567$ (per Brennan CJ Dawson Toohey Gaudron McHugh Gummow and Kirby JJ)
} 
The assertion is that the issue of the Ministerial conclusiveness certificate resulting in the non-disclosure of information about 'political issues' falls within the first test, accepting that 'law' here includes executive as well as legislative action. It is submitted the Court should have then asked whether such an exercise then was reasonably appropriate and adapted to a legitimate end that was consistent with representative and responsible government. Of course although mentioned in the Federal Court, this was apparently not argued before the High Court in the McKinnon case. However, the author submits that this is an issue which should have been considered, and the author finds it hard to reconcile the decision in McKinnon itself with the implicit (negative) right to political free communication that the High Court has recognised in a large number of cases. The author agrees with Mason CJ in $A C T v C t h^{39}$ about the need for the court's astuteness in not accepting at face value claims by the legislature and/or executive that freedom of communication would corrupt or distort the political process. These comments are considered particularly apt here in relation to the Minister's grounds for refusing release of information in this case.

The author's view is that the High Court, having accepted that the first limb in Lange was satisfied, should have considered whether the Ministerial discretion in this case was consistent with our system of responsible and representative government (emphasis added). By an interesting coincidence, responsible government was raised by members of the High Court, though as a reason for withholding the information. Callinan and Heydon JJ accepted the Government assertion that documents prepared for possible responses by Ministers in Parliament should remain confidential because their exposure would 'threaten the Westminster system of government, that is to say responsible government ${ }^{40}$ (emphasis added).

Of course, the Westminster system of government comprises many features; while responsible government is certainly one, equally representative government is another. Representative government is described by Mill as one where:

Sovereignty, or supreme controlling power in the last resort, is vested in the entire aggregate of the community, every citizen not only having a voice in the exercise of that ultimate sovereignty, but being, at least occasionally, called on to take an actual part in the

\footnotetext{
39145

${ }^{40} 1575$
} 
government by the personal discharge of some public function, local or general ${ }^{41}$

The author submits that part of having a voice in the exercise of that ultimate sovereignty is to find out the basis on which decisions have been taken by the representatives of the people. The people cannot exercise the sovereignty they possess if they cannot hold their representatives accountable for the decisions they make, and they cannot form an informed judgment about their representatives if they are left in the dark about the research background against which their representatives have made decisions. ${ }^{42}$ It would surely be to turn representative government on its head to say that the representatives of the people could mandate the information to which the sovereign people should have access in informing their exercise of sovereign rights. ${ }^{43} \mathrm{McHugh}$ $\mathrm{J}$ has made the explicit link between freedom of expression and representative government, concluding that 'if the institutions of representative and responsible government are to operate effectively, and as the Constitution intended, the business of government must be examinable and the subject of scrutiny and debate'. ${ }^{4}$

Others have made the link between FOI law and citizens' participation in government. Owen J from the Supreme Court of Western Australia noted:

The implied (right to freedom of expression) was a manifestation of the concept of representative democracy and the rationale upon which it rested was a relevant consideration that the Commissioner was obliged to take into account in determining the public interest (in disclosure). ${ }^{45}$

${ }^{41}$ John Stuart Mill Considerations on Representative Government (1861) p42

${ }^{42}$ As Fitzgerald himself said, 'if the public is not informed, it cannot take part in the political process with any real effect' (Report of a Commission of Inquiry into Possible Illegal Activities and Associated Police Misconduct) p126

${ }^{43}$ As Peter Bayne says ('Recurring Themes in the Interpretation of the Commonwealth Freedom of Information Act' (1996) 24 Federal Law Review 287, 290: 'it should be recognised that our system is one of representative democracy, because ultimately the citizens of Australia are the source of all government power. This is turn suggests that the FOI Acts be interpreted in ways which will facilitate access by the citizenry to information held by government'.

${ }^{44}$ Australian Capital Television Pty Ltd v Commonwealth (1992) 177 CLR 106, 231

${ }^{45}$ Manly $v$ Minister of Premier and Cabinet, unreported Supreme Court of Western Australia, 15/6/95. Speaking in a different context, Mason J in Commonwealth $v$ John Fairfax and Sons Ltd (1980) 147 CLR 39 stated that 'it is unacceptable in our democratic society that there should be a restraint on the publication of information 
As the Queensland Information Commissioner stated in Re Eccleston ${ }^{46}$ :

Citizens in a representative democracy have the right to seek to participate in and influence the processes of government decisionmaking and policy formulation on any issue of concern to them. The importance of FOI legislation is that it provides the means for a person to have access to the knowledge and information that will assist a more meaningful and effective exercise of that right. ${ }^{47}$

The Commissioner noted that the enhancement of public participation in government was not an explicit purpose of the FOI law, but was implicit in some of its concepts. This point has also been made by other tribunals, ${ }^{48}$ Government Ministers introducing FOI laws in some states, ${ }^{49}$ and academics. $^{50}$

relating to government when the only vice of that information is that it enables the public to discuss, review and criticise government action' (52).

${ }^{46}$ Eccleston and Department of Family Services and Aboriginal and Islander Affairs [1993] QICmr 2, para 71

${ }^{47}$ The Information Commissioner referred to an article by David Feldman ('Democracy, the Rule of Law and Judicial Review' (1990) 19 Federal Law Review $1,2-4$, where the author referred to a number of higher order rights implied by a democratic system of government, including the right of citizens to access the machinery of political decision-making).

${ }^{48}$ In Re Cleary and Department of the Treasury (1993) 18 AAR 83, 87 the Tribunal stated that the FOI Act was predicated on a set of values which have at their core the promotion of democratic processes of government; refer also to the Western Australia Information Commissioner in Re Veale and Town of Bassendean, unreported Information Commissioner of Western Australia, 1994, Decision Ref D00494.

${ }^{49}$ Former Deputy Premier of New South Wales, Wal Murray, in his second reading speech introducing the FOI bill into New South Wales Parliament spoke about the bill encompassing openness, accountability and responsibility. He said that some people felt powerless because they knew that many decisions affecting them were made by anonymous public officials, and based on information not available to the public. The FOI law was designed to remedy the situation (Legislative Assembly Debates NSW 2/6/1988 p1399). Former Queensland Attorney-General Dean Wells commenting in introducing the Queensland Act that it "enables people to have access to documents used by decision makers and will, in practical terms, produce a higher level of accountability and provide a greater opportunity for the public to participate in policy making and government itself' (Parliamentary Debates, 5/12/91, p3849). The Electoral and Administrative Review Commission's Report on Freedom of Information (December 1990 No90/86) found that 'the fairness of decisions made by 
Mason CJ in Australian Capital Television v Cth asserted that:

The very concept of representative government and representative democracy signifies government by the people through their representatives ... representatives who are members of Parliament and Ministers of State are not only chosen by the people but exercise their legislative and executive powers as representatives of the people. And in the exercise of those powers the representatives of necessity are accountable to the people for what they do and have a responsibility to take account of the views of the people on whose behalf they act ... Indispensable to that accountability and that responsibility is freedom of communication, at least in relation to public affairs and political discussion. Only by exercising that freedom can the citizen communicate his or her views on the wide range of matters that may call for, or are relevant to, political action or decision. Only by exercising that freedom can the citizen criticise government decisions and actions, seek to bring about change, call for action where none has been taken and in this way influence the elected representatives ... Absent such a freedom of communication, representative government would fail to achieve its purpose, namely government by the people, through their elected representatives; government would cease to be responsive to the needs and wishes of the people, and in that sense would cease to be truly representative $e^{51}$

government, and their accuracy, merit and acceptability, ultimately depend on the effective participation by those who will be affected by them' (para 3.36).

${ }^{50}$ Peter Bayne 'Recurring Themes in the Interpretation of the Commonwealth Freedom of Information Act' (1996) 24 Federal Law Review 287, 288: 'The High Court decisions are not authority for a proposition that the right to political free speech embraces a right to obtain information from the government. There is, however, a relationship of affinity between that freedom and the FOI laws because the latter are also premises upon the values of democracy and representative government which underpin the constitutional right of free speech'; refer also to Peter Bayne 'Freedom of Information and Democracy: A Return to the Basics?' (1994) 1 Australian Journal of Administrative Law 107; and 'Freedom of Information and Political Free Speech' in T Campbell and W Sadurski eds Freedom of Communication (1994) p199. Finn refers to the public availability of information as an important value to be promoted within a democratic society: Official Information (Integrity in Government Project: Interim Report 1)(1991) p85. Refer also to Anne Cossins 'Revisiting Open Government: Recent Developments in Shifting the Boundaries of Government Secrecy Under Public Interest Immunity and Freedom of Information Law' (1995) 23 Federal Law Review 226

${ }^{51} 137-138$ 
It is submitted the majority view is not compatible with this principle.

\section{A Reasons for Non-Disclosure}

The author submits that the decision creates some difficulties with its approach to assessing the reasons for non-disclosure, as well as the reasons that were acceptable to a majority of the court in justifying non-disclosure. Certainly, this is not the first Act conferring a broad discretion on the Executive that is said to be exercised in an inappropriate way. Just as the courts have fought to impose restraints on the exercise of what might appear to be very broad ministerial discretions in other contexts, it is submitted that it is legitimate for the Court to do so here. In other contexts, the Court has held firm against attempts by the legislature to intrude on review of executive action. ${ }^{52}$ The principle of separation of powers requires no less and it is a fundamental aspect of our constitutional arrangements.

There are comments by some current members of the High Court in similar contexts that the finding of the Minister should be (substantively) reviewable. Gummow $\mathrm{J}$ for example in Minister for Immigration $v$ Eshet ${ }^{53}$ referred with apparent approval to comments by Brennan $\mathrm{J}$ in Kruger $v$ The Commonwealth ${ }^{54}$ that:

When a discretionary power is statutorily conferred on a repository, the power must be exercised reasonably, for the legislature is taken to intend that the discretion be so exercised

\footnotetext{
${ }^{52}$ Refer for example to Chu Kheng Lim and Another v Minister for Immigration, Local Government and Ethnic Affairs and Another (1992) 176 CLR 1, and Plaintiff S157/2002 v Commonwealth (2003) 211 CLR 476. Refer to Caron Beaton-Wells 'Judicial Review of Migration Decisions: Life After S157' (2005) 33 Federal Law Review 141. The concerns raised in this article should not be taken to imply that the author believes the discretion here has been exercised more outrageously than discretions in other contexts. This is certainly not the case. It is reiterated that the review here was of a more limited nature than might occur in other contexts, involving the challenge to the reasonableness of the Minister's view about public interest.

53 (1999) 197 CLR 611

54 (1997) 190 CLR 1, 36
} 
The authority that fails to comply with this obligation acts unlawfully or ultra vires. ${ }^{55}$ This possibility was also canvassed by McHugh, Gummow and Kirby $\mathrm{JJ}$ in a recent judgment. ${ }^{56}$

The author cannot agree with the reasoning in the joint judgment that if one reasonable ground for the claim of contrariety to the public interest exists, even though there may be reasonable grounds the other way, the conclusiveness will be beyond review. With respect, this interpretation is argued to be contrary to the spirit of freedom of information laws which create a general requirement of disclosure, subject to necessary exceptions. There would always be at least one reasonable ground upon to claim disclosure would be contrary to public interest. As the minority point out, confidentiality of governmental deliberations is always a reasonable consideration. One could add that the material might be the subject of a question in Parliament, or that disclosure of written documents might inhibit the documentation of advice which if purely verbal would not be obtainable, would also always be reasonable considerations. Yet if any of these reasons, or a combination of them, could be blandly asserted each time a Minister did not find it convenient for information to be disclosed, such that access could be denied to an interested person, the whole point of freedom of information legislation would be undermined. A court or tribunal's power to review Ministerial action on the ground of reasonableness would be rendered virtually meaningless. ${ }^{57}$ The checks and balances on the Minister's power would be insufficient.

Surely, the public interest could be advanced as a reason either pointing towards or away from disclosure. Just as the Minister presumably weighed these factors up in making his/her decision under s36, surely so a reviewing tribunal must do in reviewing the decision made, not (in this context) to determine whether disclosure was in fact in the public interest or not ie not to revisit the decision, but to consider whether there were reasonable grounds for the claim that disclosure was not in the public interest. The author respectfully agrees with the position of Conti $\mathrm{J}$ in this respect. It is merely

${ }^{55}$ De Smith's Judicial Review of Administrative Action

${ }^{56}$ Re Minister for Immigration and Multicultural Affairs; Ex Parte Applicant S20/2002 (2003) 77 ALJR 1165, per McHugh and Gummow JJ (1179) and Kirby J (1188)

${ }^{57}$ Of course, the Commonwealth Constitution posits a separation of powers: $R v$ Kirby; ex parte Boilermakers' Society of Australia (1956) 94 CLR 254; AttorneyGeneral (Cth) v R; Ex Parte Boilermakers' Society of Australian (1957) 95 CLR 529; Kable v Director of Public Prosecutions (NSW)(1996) 189 CLR 51 
considering one factor to consider whether a reasonable ground existed to support the Minister's decision - that is not how the Minister would have made the decision; it is not how the decision should be reviewed. It is submitted that 'reasonable grounds' means that arguments in favour of and against disclosure have been considered. This is admittedly partly a policy decision - the alternative is that one reasonable ground is sufficient, and as has been noted, it will always be possible to find at least one reasonable ground.

One might refer to cases decided on the common law principle of Crown immunity decided prior to the introduction of the FOI Act on the issue of reasonableness. ${ }^{58}$ While the author is aware of the different factual context in which Sankey arose, of course, it is permissible to examine the previous common law to assist in interpreting a statute where there is ambiguity, and the difference of opinion on the High Court in this case shows that there is ambiguity in how s36 must be applied. For example, in Sankey $v$ Whitlam $^{59}$ members of the High Court referred to a decision about the public interest in the context of disclosure as a balancing exercise. ${ }^{60}$ Stephen J stated that it was 'the task of a court, in dealing with a claim to Crown privilege, to weigh competing public interests'. ${ }^{61}$ Mason J noted that:

In considering an objection to production on the ground of Crown privilege the court must evaluate the respective public interests and determine whether on balance the public interest which calls for nondisclosure outweighs the public interest in (favour of disclosure) ... In determining this question the court, though it will give weight to the Minister's opinion that the documents should not be produced, is

\footnotetext{
${ }^{58}$ This is the limited extent to which Sankey is submitted to be useful - the author concedes that case involved a criminal prosecution.

${ }^{59}$ (1978) 142 CLR 1. I acknowledge this was not an FOI case but believe it is relevant to the present discussion, dealing with relevant common law principles. ${ }^{60}$ Citing with approval the House of Lords decisions in Conway v Rimmer [1968] AC 910 (especially Lord Reid (990-995), Lord Morris (956-957,972), Lord Pearce (986-987) and Lord Upjohn (992); Rogers v Home Secretary [1973] AC 388, and the decision of the United States Supreme Court in United States v Nixon (1974) 418 US 683. Lord Pearson was adamant in Rogers that in applying the doctrine of public interest, 'the court has to balance the detriment to the public interest on the administrative or executive side, which would result from the disclosure of the document or information, against the detriment to the public interest on the judicial side, which would result from the non-disclosure of a document or information' (406)

${ }^{61}$ P58
} 
entitled to inspect the documents and form its own conclusion upon the question whether the public interest will be better served by production or non-production ${ }^{62}$

Adapting Mason J's words to the slightly different legislative formulation here which specifies a limited range of judicial review rather than a full merits review of the Minister's opinion, it is submitted that the court must conduct a balancing exercise in order to determine whether the Minister's opinion is a reasonable one (again, not reviewing the merits of the decision, but asking whether it is a reasonable one). In assessing whether or not the opinion is reasonable, the court must form its own conclusion, rather than rely on a bland assertion of inter-governmental confidentiality that, if accepted as a general justification, could effectively kill off freedom of information principles altogether. It is submitted that this does involve a weighing process, as the common law process acknowledged.

Again in the different context of industrial legislation, the High Court (Mason CJ, Wilson and Dawson JJ) in Re Queensland Electricity Commission; ex parte Electrical Trades Union of Australia (QEC) stated that:

Ascertainment in any particular case of where the public interest lies will often depend on a balancing of interests, including competing public interests, and be very much a question of fact and degree. ${ }^{63}$

Conti $\mathrm{J}$ in the McKinnon litigation, conceding that as with the Sankey comments they arose in a different context from the current, nevertheless referred to the $Q E C$ case to support his view of how the Tribunal should have conducted its review exercise. ${ }^{64}$ He believed the comments about public interest more generally remained apposite to the current litigation.

One of the grounds cited for non-disclosure was that release might jeopardise candour of discussions within government. Of the majority, Callinan and Heydon JJ seemed to accept this argument, concluding it 'could not readily be dismissed', ${ }^{65}$ and that the Minister's opinion on this was likely to be 'as well informed and valuable as those of anyone else'. The judgment on this ground is contained in one paragraph of their Honours' judgment, and no

\footnotetext{
${ }^{62} \mathrm{P} 96$

${ }^{63}$ (1987) 61 ALJR 393, 395; Deane J to like effect on this point (400)

${ }^{64} 90$

${ }^{65} 1575$
} 
cases are referred to by their Honours in accepting this justification for nondisclosure.

Some other judges have considered and rejected such arguments as legitimate grounds for non-disclosure, albeit in a non-FOI context. ${ }^{66}$ Mason J in Sankey $v$ Whitlam $^{67}$ (a decision to which the majority judgments of the High Court in the current case did not refer) emphatically concluded that the "possibility that premature disclosure will result in want of candour in cabinet discussions or in advice given by public servants is so slight that it may be ignored' ${ }^{68}$ Lord Reid in Conway $v$ Rimmer, ${ }^{69}$ while accepting that Cabinet minutes should generally not be released, ${ }^{70}$ added in obiter 'but I do not think that many people would give as the reason that premature disclosure would prevent candour in the Cabinet'. ${ }^{71}$ These comments are also submitted to be

${ }^{66}$ These cases were decided on common law principles rather than FOI-specific principles but they are submitted as relevant, dealing with the same issue of nondisclosure of documents on claimed public interest grounds.

${ }^{67}$ (1978) 142 CLR 1,97

${ }^{68}$ Mason J did then concede that the efficiency of government would be seriously compromised if Cabinet decisions and papers were disclosed while they or the topics to which they relate are still current or controversial (97). If the topic was no longer current, the risk of injury to the efficient working of government became slighter, so disclosure would be feasible (98).

${ }^{69}$ [1968] AC 910, 952

70 'Virtually everyone agrees that Cabinet minutes ... ought not to be disclosed until such time as they are of historical interest ... the most important reason is that such disclosure would create or fan ill-formed or captious public or political criticism ... the business of government is difficult enough as it is, and no government could contemplate with equanimity the inner workings of the government machine being exposed to the gaze of those ready to criticise without adequate knowledge of the background and perhaps with some axe to grind' (99). Mason J in Sankey v Whitlam, while agreeing generally with these remarks, did not think that the possibility of illinformed criticism and its inconveniences was the reason, preferring the justification that decision making would be difficult if the decision making processes of Cabinet and the materials on which they were based were at risk of premature publication (97). Lord Reid's comments have not escaped criticism: see for example Eagles 'Cabinet Secrets as Evidence' (1980) Public Law 263, 269 who claims it is unlikely that hard decisions will be avoided or that Cabinet will be swayed by pressure groups any more than currently is the case, if disclosure rights were broader. The Queensland Information Commissioner does not think Lord Reid's comments reflect the position in Australia given Mason J's views in Fairfax and ACT $v$ Commonwealth (No2): Re Eccleston and Department of Family Services and Aboriginal and Islander Affairs (1994) 1 QAR 60, 100-101

${ }^{71}$ Similar comments appear in the judgment of Lord Radcliffe in the Glasgow Corporation Case (1956) S C (HL) p20 who thought that he would have supposed Crown servants to be made of 'sterner stuff' (than to be worried about disclosure 
analogous to candour within a government department. They are made in a different context, but this does not affect the sentiment.

Another ground cited in favour of non-disclosure was that the material was tentative, including matters that were not settled and recommendations that were not adopted. Callinan and Heydon JJ accepted that the Minister's decision that 'material of that kind would not make a valuable contribution to public debate' was a reasonable one. ${ }^{72}$ With respect, the spirit of the freedom of information laws is surely that it is not up to the Minister to decide finally what information should be released and what information should not be released. If this were the case, there would be no need for FOI legislation. The right of access FOI legislation grants is for an obvious reason - if it were the government's decision, the government might be inclined to release only information deemed favourable to them, or deemed unlikely to cause concern to voters. As Mason $\mathbf{J}$ pointed out in Commonwealth of Australia v John Fairfax and Sons Ltd: ${ }^{73}$

It is unacceptable in our democratic society that there should be a restraint on the publication of information relating to government when the only vice of that information is that it enables the public to discuss, review and criticise government action.

If a Court were to blindly accept at face value the assertion of a Minister that release of information would not make a valuable contribution to public debate, the Government may well be tempted to block the release of information that would entitle the public to 'discuss, review and criticise government action'. Of course, it may not be convenient for a government for the public to be involved in a critical debate of a government policy or decision. For this reason, the author submits that the court should not merely accept at face value an assertion by a member of the Executive that release of the information would not valuably contribute to public debate. With respect, the Information Commissioner, Tribunal or Court as interpreters of the FOI

such that candour would be inhibited), and Lord Salmon in Rogers v Home Secretary [1973] AC 413 referred to the candour argument as the 'old fallacy'. The position was summarised in Re Wallace and Merit Protection and Review Agency (1995) 38 ALD 773, 775-776 that 'the trend of the cases is in favour of giving weight to the objects of the FOI Act over submissions arguing a lack of candour would result if disclosure is ordered'. Candour is one of the factors mentioned in the nowdiscredited Re Howard and The Treasurer of the Commonwealth of Australia (1985) 3 AAR 169,176.

${ }^{72} 1575$

73 (1980) 147 CLR 39,52 
legislation are the arbiters of what information is accessible or not under the legislation; not the government. ${ }^{74}$ The principle of separation of powers requires the amenability of Ministerial decision making to review, ${ }^{75}$ which should not be watered down. ${ }^{76}$ In the context of the specific wording of s36, the Minister should be required to demonstrate the specific reasonableness of this view that this information would not be valuable as part of a contribution to public debate. Mere assertion is not satisfactory to this writer. ${ }^{77}$

\section{B Other Criticisms}

A further suggested interpretation difficulty with the decision is how the court dealt with evidence relating to the object of the FOI law. Section 15AA of the Acts Interpretation Act 1901 (Cth) makes clear, and s3(2) of the Freedom of Information Act 1982 (Cth) reinforces, that Commonwealth legislation must be interpreted in a manner consistent with the objects for which the law was passed. In this light, it is curious that the interpretation used by Callinan and Heydon JJ is, as they expressly acknowledge, 'may' practically lead to the consequence that one or more of the stated objects of the Act is thereby defeated. Their Honours claim this consequence is caused

\footnotetext{
${ }^{74}$ Acting Chief Justice Gibbs made the same point in relation to the common law in Sankey $v$ Whitlam (1978) 142 CLR 1,38: 'It is in all cases the duty of the court, and not the privilege of the executive government, to decide whether a document will be produced or may be withheld'.

${ }^{75}$ Some might argue it is the decision of the Tribunal, rather than the decision of the Minister, that is under challenge. This might be technically correct, but since the decision of the Tribunal is about the decision of the Minister, it is submitted that indirectly or defacto the court's review here concerns the decision of the Minister.

${ }^{76}$ There is a significant literature in Australia on the principle of separation of powers. Refer for example to George Winterton 'The Separation of Judicial Power as an Implied Bill of Rights' in Geoffrey Lindell ed Future Directions in Australian Constitutional Law (1994); Elizabeth Wheeler 'Original Intent and the Doctrine of the Separation of Powers in Australia' (1996) 7 Public Law Review 96; Finnis 'Separation of Powers in the Australian Constitution' (1967) 3 Adelaide Law Review 159; Elizabeth Handsley 'Public Confidence in the Judiciary: A Red Herring for the Separation of Judicial Power' (1998) 20 Sydney Law Review 183; Fiona Wheeler 'The Rise and Rise of Judicial Power Under Chapter III of the Constitution: A Decade in Overview' (2000) 20 Australian Bar Review 283; and Anthony Gray 'Alert and Alarmed: The National Security Information Act' (2006) 24(1) University of Tasmania Law Review 1.

${ }^{77}$ Again, this is not to suggest that the Court is substituting its decision for that of the original decision maker.
} 
by the 'unmistakable' language of the FOI Act. ${ }^{78}$ One might respectfully quibble with their classification of the language as 'unmistakable'. The concept of public interest is inherently not suitable for precise definition, ${ }^{79}$ as the Australian Senate Committee on Constitutional and Legal Affairs considering the draft Commonwealth FOI laws noted. ${ }^{80}$ That Committee expressly declined to define public interest for that reason.

Given that the concept of public interest is flexible, should a court not if possible (and should a Minister not if possible) interpret the test of public interest in a manner consistent with the objectives of the Act in which the test appears? It would be one thing if this were not possible; however clearly it was possible in the Act in question here, as the minority did. It is surely a basic principle of statutory interpretation that, where possible, sections of an Act should be interpreted consistently with the stated objects of the Act. That is indeed a primary reason for including express objects in the first place.

\section{CONCLUSION}

It is submitted that the majority judgment in McKinnon gives an unduly narrow scope to the federal Freedom of Information Act in, indirectly, allowing Ministers to avoid compliance with the Act by merely issuing a certificate that the disclosure of the material would be contrary to the public interest. ${ }^{81}$ Although the Act does not provide for a full merits review of this decision, it is suggested that the High Court needs to more rigorously review the assessment of the Executive in this regard, to ensure that the objects of FOI law are met. The Constitution and its principles of representative government and separation of powers requires no less.

It has been argued that, consistently with the Constitution, the doctrine of representative government, as well as the inherent sovereignty of the people, the High Court should take a broader view of freedom of information rights.

\footnotetext{
${ }^{78}$ This is presumably a reference to $\mathrm{s} 36$ of the Act, containing the relevant exemption.

${ }^{79} R$ v Trade Practices Tribunal; Ex Parte Tasmanian Breweries Pty Ltd (1970) 123 CLR 361

${ }^{80}$ Senate Standing Committee on Constitutional and Legal Affairs Report on the Freedom of Information Bill 1978 and Aspects of the Archives Act 1978, AGPS, Canberra, 1979 p66; to like effect Senate Standing Committee on Constitutional and Legal Affairs Report on the Operation and Administration of the Freedom of Information Legislation, AGPS, Canberra, 1987 p155
} 
Citizens cannot make informed decisions as to who is best to represent them if they can be easily prevented from obtaining detailed information about government decision making. The decision is hard to reconcile with previous decisions, albeit in a non-FOI context. Further, a reading of the FOI Act as a whole would tend to favour a broad construction of access rights, rather than allowing a government to suppress documents thought to be politically sensitive. 
